\title{
Quantitative Gas Chromatographic Method for the Analysis of cis and trans Fatty Acid in Margarines
}

(Kaedah Kuantitatif Gas Kromatografi untuk Analisis Asid Lemak cis dan trans dalam Sampel Marjerin)

\author{
JUMAT SALIMON*, TALAL AHMED \& NADIA SALIH
}

\begin{abstract}
Fats and oils in human diets are the main sources of essential fatty acids for the body. However, there is a mounting concern about the intake of foods containing trans fatty acids (TFAs) due to their deleterious effects on human. Thus, the accurate detection of fatty acids (FAs) and TFAs is needed to control and correct nutrition labeling in dietary fat samples. Accordingly, a method for the identification and quantification of FAs and TFAs in food fats by gas chromatography $(G C)$ based on the extraction of lipids and derivatization using base catalyzed followed by trimethylsilyl-diazomethane (TMS-DM) was developed. The proposed method was evaluated to standard mixture of oleic acid (OA) (C18:1 cis 9) and Elaidic acid (EA) (C18:1 trans 9) and its application to three samples of commercial margarines was demonstrated. Based on the results obtained, recovery values $(R)$ from all the samples were close to $100 \%$. Repeatability (RSD) values ranged between 0.78 and $2.47 \%$, while Reproducibility (RSD) values ranged between 1.14 and $3.65 \%$. Consequently, the proposed method is sensitive, accurate and suitable for FAs and TFAs analysis of food fats and oils and can be applied to nutritional, medicine and food studies.
\end{abstract}

Keywords: Derivatization; food fats; quantitative analyses; trans fatty acids

\section{ABSTRAK}

Minyak dan lemak dalam pemakanan harian merupakan sumber utama asid lemak yang diperlukan dalam tubuh manusia. Namun begitu, kesedaran yang ting gi terhadap pengambilan makanan yang mengandungi asid lemak trans (TFAs) wujud disebabkan oleh kesan buruk terhadap manusia. Oleh itu, kaedah penentuan secara tepat kandungan asid lemak (FAs) dan TFAs amat diperlukan bagi tujuan pengawalan dan perlabelan kandungan nutrien dalam sampel makanan berlemak. Suatu kaedah pengenalpastian dan penentukuran kandungan FAs and TFAs dalam sampel makanan berlemak secara gas kromatografi (GC) berasaskan kepada pengekstrakan lipid dan penterbitan menggunakan mangkin bes diikuti oleh trimetilsilil-diazometana (TMS-DM) telah dibangunkan. Kaedah cadangan telah dinilai dan diuji menggunakan sampel campuran piawai asid oleik (OA; C18:1 cis 9) dan asid elaidik (EA; C18:1 trans 9) dan penggunaannya terhadap tiga sampel marjerin dagangan telah ditunjukkan. Hasil kajian menunjukkan bahawa nilai kebolehdapatan ( $R$ ) daripada setiap sampel kajian adalah menghampiri 100\%. Nilai kebolehulangan RSD adalah dalam julat 0.78 hing ga $2.47 \%$, sementara nilai kebolehhasilan RSD adalah dalam julat 1.14 hingga 3.65\%. Oleh itu kaedah cadangan terbukti merupakan suatu kaedah yang sensitif, tepat dan sesuai untuk penganalisan kandungan FAs and TFAs dalam sampel makanan berlemak dan boleh digunakan dalam bidang pemakanan, perubatan dan kajian makanan.

Kata kunci: Analisis kuantitatif; asid lemak trans; makanan berlemak; penterbitan

\section{INTRODUCTION}

The significance of FAs and TFAs analysis has gained much attention because of the nutritional and health implications on human (Mozaffarian et al. 2006). Naturally, all unsaturated FAs in the vegetable oils are in the cis-form. While, a large proportion of unsaturated FAs isomerise to their TFA counterparts during industrial hydrogenation of dietary fats and oils. Thus, food products made with such hydrogenated fats and oils such as margarines, shortenings, confectionery fats and bakery products also contain TFA (Bhanger \& Anwar 2004; Tarrago-Trani et al. 2006). The association between dietary consumption of some cis/trans FAs and increased risk of cardiovascular disease has led to the implementation in several countries of new regulations requiring the declaration of FAs including TFA content on the labels of dietary fats and oils products (Wassell \& Young 2007). Accordingly, accurate methods for measurement of cis and trans FAs with adequate sensitivity and accuracy are needed to achieve those objectives (Backholer \& Peeters 2012; Mossoba et al. 2007).

Gas chromatography coupled with flame ionization detector (FID) is the most widely used technique for determination of FAs and TFA (Delmonte \& Rader 2007; Jumat et al. 2006). Several methods are commonly used for conversion the FAs into FA methyl esters (FAMEs) either by base or acid-catalyzed esterification including officially recognized methods (Delmonte \& Rader 2007; Nimal Ratnayake 2004). Despite such methods employed 
for total FA analyses in different food samples, there are still contradictory opinions about the most suitable and satisfactory methods for overcoming all the difficulties posed by the analysis of complex mixtures including TFA isomers due to the chemical instability of FAs and change the distribution of cis and trans isomers entering GC (Ackman 1998; Phillips et al. 2010). Otherwise, the presence of nonlipids at the moment of the derivatization process may lead to interference with lipids and that causing potential errors and high variable profiles (Harmanescu 2012; Juàrez et al. 2008).

Therefore, the need for fast and accurate methods for extracting the lipid and determining the FA has led to develop the accurate method in order to overcome the shortcomings that may effect on the sensitivity of the analysis procedure. The alkali-based transesterification method has resulted in poor $\mathrm{R} \%$ of FAMEs due to free FAs might remain partially unreacted (Juàrez et al. 2008). However, it is possible to apply the advantages of sodium methoxide $\left(\mathrm{NaOCH}_{3}\right)$ as a useful reagent for fast transformation of FAs into FAMEs (Christie 1993) along with using TMS-DM reagent for complete methylation of all FFAs where the TMS-DM has been reported to be effective in methylating FFAs and more accurate for cis/trans FAs analysis in seafood and in ruminant meat tissues (Aldai et al. 2005). Consequently, the proper extraction and esterification allow to complete separation and quantify in a single chromatogram a complex mixture of FAs and TFA such as OA and EA, respectively and may overcome the problems affecting the accuracy and sensitivity of analysis fats and oils.

The aim of this work was to develop a GC method for the analysis of FAs and TFAs mixture. The method is based on the chemicals derivatization of extracted lipid by using $\mathrm{NaOCH}_{3}$ followed by TMS-DM in order to improve the peak configuration, the separation of cis and trans isomers and increase the accurate quantification of the wide range FAs and TFAs concentrations in fats and oils samples such as margarine and shortenings. The resolution of OA and EA was used as the criterion of cis and trans isomers of FA during the validation procedure, as well as during the application method in analyzing three of margarine samples.

\section{MATERIALS AND METHODS}

\section{REAGENTS AND STANDARDS}

All chemicals, solvents and reagents employed were analytical grade and purchased from Malaysia (Systerm, Malaysia). The individual standards of OA \& EA, the internal standard (IS) C15:0 (Pentadecanoic acid) and the esterifying agent TMS-DM (2M) in n-hexane were purchased from Sigma (Sigma-Aldrich, Germany) and the purity was at least $99 \%$. A standard mixture containing OA and EA was used to prepare the stock solution (Std 1). Calibration curves were produced from five working standard sets (Std 2, 3, 4, 5 and 6) which were prepared daily from Std
1 by diluting with n-hexane (from 0.1 to $20 \mu \mathrm{g} / \mathrm{mL}$ ) and a known concentration of IS was added to the samples. All the mixtures of the working standards and IS were stored at $-20^{\circ} \mathrm{C}$ until analysis.

\section{PREPARATION OF FAMES}

Each one of the working standards was first processed with hexane and FAMEs were prepared by using $1 \mathrm{~mL}$ of $2 \mathrm{M}$ $\mathrm{NaOCH}_{3}$ in a water bath at $60^{\circ} \mathrm{C}$. Drops of concentrated glacial acetic acid were added to neutralize the $\mathrm{NaOH}$. After flushing with nitrogen $\left(\mathrm{N}_{2}\right)$, the samples were redissolved in $1 \mathrm{~mL}$ of methanol: toluene (2:1 vol.) and 100 $\mu \mathrm{L}$ of TMS-DM (2M) in n-hexane was added at $60^{\circ} \mathrm{C}$ for $5 \mathrm{~min}$. Drops of glacial acetic acid were added until the yellow color disappeared to remove unreacted TMS-DM and the reaction mixture was diluted with $1 \mathrm{~mL}$ of $0.5 \% \mathrm{NaCl}$ solution. Methyl esters were extracted twice in hexane containing $50 \mathrm{ppm}$ BHT $(2 \times 1 \mathrm{~mL})$ and the upper hexane layers containing the FAMEs were pooled and dried down under $\mathrm{N}_{2}$ before they stored at $-20^{\circ} \mathrm{C}$ until GC analysis .

\section{GC ANALYSIS OF FAME}

FAMEs in all the test tube samples were re-dissolved in 100 $\mu \mathrm{L}$ hexane and $1 \mu \mathrm{L}$ volume of each sample was injected five times into GC-FID (Shimadzu, GC-17A, Kyoto, Japan) for separation and quantification of the FAMEs using a BPX70 fused silica capillary column and run under an optimized temperature program (initial column temperature $100^{\circ} \mathrm{C}$, programmed to increase up to final temperature of $260^{\circ} \mathrm{C}$ ) with optimized gas flow rate of $1 \mathrm{~mL} / \mathrm{min}$. The method was subject to validation according to guidelines for validation of chromatographic methods (Taverniers et al. 2004). The validation procedure included detector response linearity, sensitivity, recovery and precision assays.

\section{MARGARINE SAMPLES ANALYSIS}

In order to demonstrate the applicability of the proposed method, FA constituents of the margarines samples, purchased from Malaysian local supermarket and coded with $\mathrm{A}, \mathrm{B}$ and $\mathrm{C}$ were identified and quantified by accurately weighing $150 \mathrm{mg}$ aliquots of the homogenized samples into extraction tubes and a known concentration of IS was added to the samples. Lipid extracts were prepared by homogenizing the samples in $20 \mathrm{~mL}$ of hexane containing (50 ppm BHT). After the filtration, the solvent was removed under vacuum in a rotary evaporator. The extraction procedure was repeated once more. After the extraction process, FAMEs were prepared using the same procedures as described earlier and injected $(1 \mu \mathrm{L})$ five times in the GC under the same conditions.

\section{RESULTS AND DISCUSSION}

FAMEs in mixtures were identified by comparison of similar peak retention times (RT) using pure FAME standards. Figure 1 shows a partial gas chromatogram of OA and EA methyl 
esters injected at different levels of concentration and which obtained of the working standard sets from Std 2 to 6 by using the proposed procedure outlined before. Calibration curves were constructed from the analyses in triplicate of the aforementioned working standards (according to the Multiple Point I.S. method) for quantitative purposes. The calibration curves of OA and EA are shown in Figures 2 and 3 , respectively.

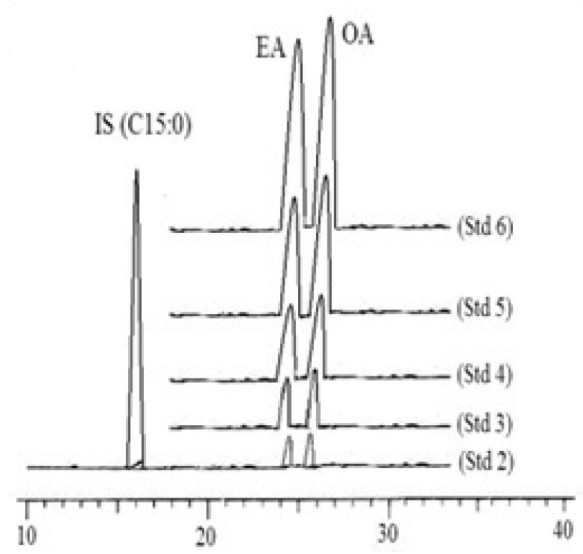

FIGURE 1. Partial gas chromatogram of IS, OA and EA methyl esters injected at different levels of concentration by using the proposed method

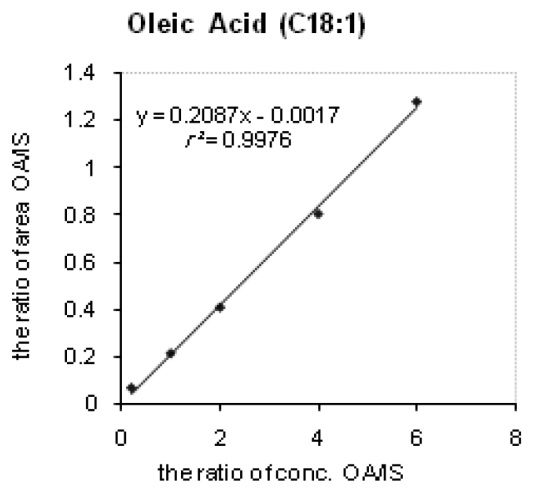

FIGURE 2. The calibration curve of oleic acid established by using the ratio of FAME peak area to IS peak area, against the ratio of FAME to IS
Elaidic Acid (C18:1 t9)

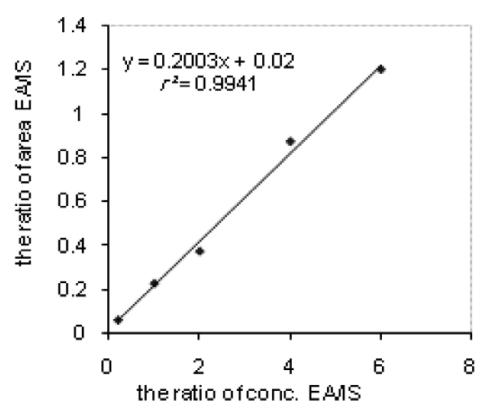

FIGURE 3. The calibration curve of elaidic acid established by using the ratio of FAME peak area to IS peak area, against the ratio of FAME to IS

Separate calibration plots were used to calculate the linear response of both FAs in the FID detector. Table 1 presents the equations and correlation coefficients $\left(r^{2}\right)$ of the calibration curves. As observed from the data, the results were found to be linear over the concentration range studied and $r^{2}$-values were higher than 0.99 . The slope values of the regression lines were similar (almost 0.21 ), indicative of similar detector calibration sensitivity for each analyte (Pierluigi \& Jeanne 2007).

Repeatability and reproducibility replications were used to measure the precision of the quantitative method. The repeatability of the method was established from six $(n=6)$ complete analyses of each sample under the same conditions in a day and the reproducibility was established from three $(n=3)$ complete analyses of each sample repeated three consecutive days. Table 1 shows the repeatability and the reproducibility which expressed by the relative standard deviation (RSD \%). As observed from the data, average values for repeatability of OA and EA samples was 0.78 and $1.03 \%$, respectively and average values for reproducibility of both analyte samples was 1.14 and $1.27 \%$, respectively. These values reflect the high precision of this proposed method due to lower $\mathrm{RSD} \%$ variation values for OA and EA as compared to the laboratory findings of the some methods which have been validated by some analysts (Buchgraber \& Ulberth 2002; Delmonte \& Rader 2007; Juàrez et al. 2008).

TABLE 1. Equations, correlation coefficients, repeatability, reproducibility and recovery percentage of the OA and EA determined in the mixtures standard

\begin{tabular}{lccccc}
\hline Fatty acids & $\begin{array}{c}\text { Calibration Curve } \\
\text { Equation }^{(\mathrm{c})}\end{array}$ & $\begin{array}{c}\text { Coefficient of } \\
\text { correlation }\left(r^{2}\right)\end{array}$ & $\begin{array}{c}\text { Repeatability } \\
(\text { RSD } \%)^{(\mathrm{d})}\end{array}$ & $\begin{array}{c}\text { Reproducibility } \\
(\mathrm{RSD} \%)^{(\mathrm{e})}\end{array}$ & $\begin{array}{c}\text { Recovery } \\
(\mathrm{R} \%)^{(\mathrm{f})}\end{array}$ \\
\hline${ }^{(\mathrm{a})} \mathrm{OA}$ & $\mathrm{y}=0.2502 \times+0.0013$ & 0.9993 & 0.78 & 1.14 & 98.21 \\
${ }^{(\mathrm{b})} \mathrm{EA}$ & $\mathrm{y}=0.2498 \times+0.0009$ & 0.9994 & 1.03 & 1.27 & 97.62 \\
\hline
\end{tabular}

${ }^{(a)}$ Oleic acid methyl ester. ${ }^{(b)}$ Elaidic acid methyl ester

(c) $\mathrm{y}=\mathrm{FA}$ peak area/IS peak area, $\mathrm{x}=[\mathrm{FA}] /[\mathrm{IS}]$, IS - internal standard $(\mathrm{C} 15: 0)$

(d) The mean value of RSD established from six $(n=6)$ complete analyses of each sample in a day

${ }^{(e)}$ The mean value of RSD established from three complete analyses repeated tree consecutive days

(f) The mean of recovery percentage established from the complete analysis in triplicate of FAMEs

standard fortified with $(\operatorname{std} 3)$ 
The accuracy of the proposed method was verified by means of recovery assay. The recovery percentage (R\%) of the method was established from the complete analysis in triplicate of FAMEs standard fortified with the selected working standard (Std 3). The mean values of $\mathrm{R} \%$ obtained for OA and EA studied are shown in Table 1. In general, R-values approaching 100\% (98.2 and 97.6\% for OA and EA, respectively) and this indicates that the proposed method is appropriate in terms of accuracy, credibility and reliable for quantified analysis of mixture of FA and TFA as compared with the improved standard methods (Delmonte \& Rader 2007; Phillips et al. 2010).

The margarine samples were analyzed in triplicate in order to validate and demonstrate the applicability of the proposed method. Figure 4 shows a typical FID chromatogram of total FA analysis on margarine (sample A) obtained using the proposed procedure as previously outlined.

As can be observed, the baseline separation was achieved for all components within 35 min with a good separation between FAs and TFAs peaks, thus, indicating that the peak overlapping was not interfered with by the peaks of major constituents. Furthermore, no strange peaks or artifacts interfering on the target analytes chromatographic peaks were found, in contrast to the routine analysis. This result also agree with earlier report that TMS-DM did not produce any methoxy artifacts associated with base-catalyzed (Aldai et al. 2005; Juàrez et al. 2008; Murrieta et al. 2003).

The analysis of previous samples was also used to validate the proposed method. Table 2 shows the contents of OA and EA (expressed as g FA/100 g sample), as well as the estimated results of precision and accuracy in the same way describe earlier.

Overall, R-values, which approached $100 \%$, as well as lower RSD\%-values of repeatability and reproducibility, proved that the proposed method is appropriate in terms of accuracy, precision and credibility in comparison with classic methods (Nimal Ratnayake 2004; Phillips et al. 2010). Accordingly, this method would be reliable for

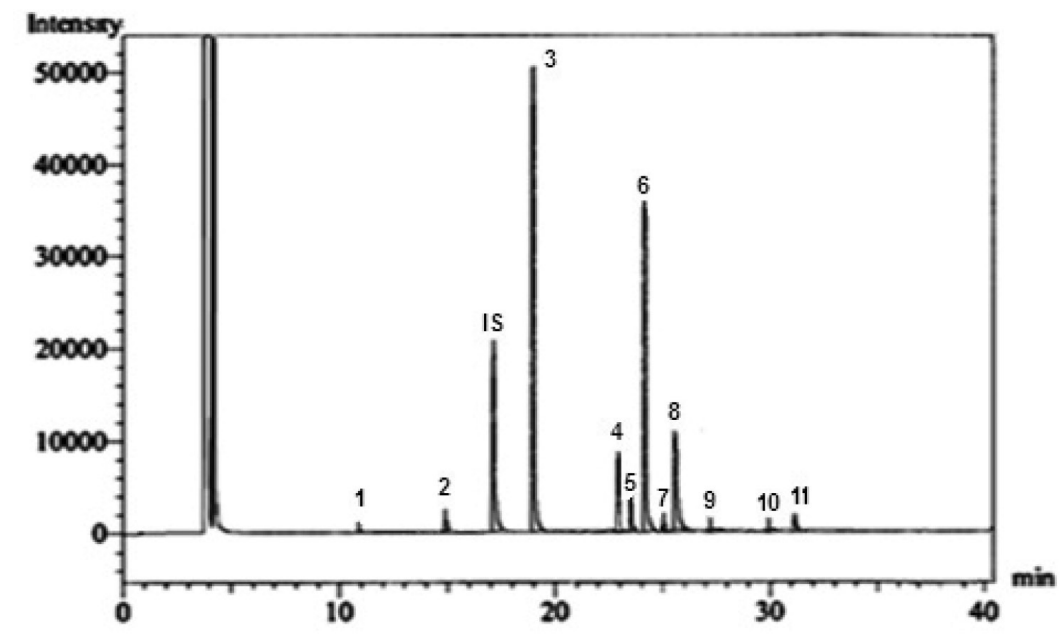

FIGURE 4. GC-FID chromatogram of margarine sample A

$(1=\mathrm{C} 12: 0 ; 2=\mathrm{C} 14: 0 ; 3=\mathrm{C} 16: 0 ; 4=\mathrm{C} 18: 0 ; 5=\mathrm{C} 18: 1 \mathrm{t} 9 ; 6=\mathrm{C} 18: 1$; $7=18: 2$ 9t,12t; $8=\mathrm{C} 18: 2 ; 9=\mathrm{C} 18: 3 ; 10=\mathrm{C} 22: 0 ; 11=\mathrm{C} 24: 0 ; \mathrm{IS}=\mathrm{C} 15: 0)$.

TABLE 2. The contents of OA and EA, and the estimated results of precision and accuracy of margarine samples studied

\begin{tabular}{lccccc}
\hline Samples & FAs & $\begin{array}{c}\text { Detected concentration } \\
\text { Mean } \pm \mathrm{SD}^{(\mathrm{c})} \\
\text { g FA per 100 sample }\end{array}$ & $\begin{array}{c}\text { Repeatability } \\
(\mathrm{RSD} \%)\end{array}$ & $\begin{array}{c}\text { Reproducibility } \\
(\mathrm{RSD} \%)\end{array}$ & $\begin{array}{c}\text { Recovery } \\
(\mathrm{R} \%)^{(\mathrm{d})}\end{array}$ \\
\hline $\mathrm{A}$ & ${ }^{(\mathrm{a})} \mathrm{OA}$ & $27.51 \pm 0.33$ & 1.19 & 1.61 & 101.45 \\
& ${ }^{(b)} \mathrm{EA}$ & $0.53 \pm 0.02$ & 1.46 & 2.51 & 98.90 \\
$\mathrm{~B}$ & OA & $23.87 \pm 0.59$ & 1.39 & 2.14 & 97.22 \\
& EA & $0.17 \pm 0.01$ & 2.47 & 3.65 & 98.46 \\
$\mathrm{C}$ & OA & $32.27 \pm 0.49$ & 1.52 & 2.01 & 95.80 \\
& EA & $\mathrm{ND}^{(\mathrm{e})}$ & - & - & 99.03 \\
\hline
\end{tabular}

${ }^{(a)}$ Oleic acid methyl ester. ${ }^{\text {(b) }}$ Elaidic acid methyl ester. ${ }^{(c)}$ Standard deviation

(d) The mean of recovery percentage established from the complete analysis in triplicate of the sample fortified with $(\operatorname{std} 3)^{\left({ }^{(e)}\right.}$ Not detected 
quantified analysis of mixture of different types of FAs and TFAs in various fats and oils samples with products of the food fats.

On the other hand, it should be noted here that the results of the analysis of some margarine product, a popular food product in Malaysian market, indicated a considerable low in the content of trans fats in those samples. It may due to the existence of palm oil as a major ingredient and or its derivatives such as palm stearin and palm kernel olein. However, the presence of small amounts of TFAs in those products might be due to isomerization during deodorization which is normally carried out at $250-260^{\circ} \mathrm{C}$ (Berger \& Idris 2005; Tang 2002). In addition, it might be due to the use of hard stearin as one of the fat sources. Hard stearin could be obtained through combination of hydrogenated palm stearin with non-hydrogenated fat (Neo et al. 2007).

\section{CONCLUSION}

The proposed GC method using the extraction of lipid and derivatization based on base-catalyzed with $\mathrm{NaOCH}_{3}$ followed by TMS-DM allows the separation and identification of cis/trans isomers (e.g., OA \& EA) and yields satisfactory results on preparing FAMEs for accurate quantification of FAs by GC. Moreover, the method validation parameters, on the standards solutions of OA \& EA and three of real samples of margarine, suggest that the procedure is sensitive, accurate, reliable and adequate for measuring of FAs and TFAs in complex mixtures. Thus, this method could be an effective tool for the analysis of FAs in different food samples for control of labeling authenticity.

\section{ACKNOWLEDGMENTS}

The authors acknowledged Universiti Kebangsaan Malaysia for the funding (DPP-2014-058 and UKMAP-2011-17) and the School of Chemical Sciences and Food Technology, Faculty of Science and Technology, UKM, for their support and encouragement.

\section{REFERENCES}

Ackman, R. 1998. Remarks on official methods employing boron trifluoride in the preparation of methyl esters of the fatty acids of fish oils. Journal of the American Oil Chemists' Society 75(4): 541-545.

Aldai, N., Murray, B.E., Nájera,A.I., Troy, D.J. \& Osoro, K. 2005. Derivatization of fatty acids and its application for conjugated linoleic acid studies in ruminant meat lipids. Journal of the Science of Food and Agriculture 85(7): 1073-1083.

Backholer, K. \& Peeters, A. 2012. Reduction of trans-fatty acids from food. The Journal of the American Medical Association 308(18): 1858-1859.

Berger, K. \& Idris, N.A. 2005. Formulation of zero-trans acid shortenings and margarines and other food fats with products of the oil palm. Journal of the American Oil Chemists'Society 82(11): 775-782.
Bhanger, M.I. \& Anwar,F. 2004. Fatty acid (FA) composition and contents of trans unsaturated FA in hydrogenated vegetable oils and blended fats from Pakistan. Journal of the American Oil Chemists' Society 81(2): 129-134.

Buchgraber, M. \& Ulberth, F. 2002. Determination of low level trans unsaturation in physically refined vegetable oils by capillary GLC-Results of 3 intercomparison studies. European Journal of Lipid Science and Technology 104(12): 792-799.

Christie, W.W. 1993. Preparation of ester derivatives of fatty acids for chromatographic analysis. Advances in Lipid Methodology 2: 69-111.

Delmonte, P. \& Rader, J.I. 2007. Evaluation of gas chromatographic methods for the determination of trans fat. Analytical and Bioanalytical Chemistry 389(1): 77-85.

Harmanescu, M. 2012. Comparative researches on two direct transmethylation without prior extraction methods for fatty acids analysis in vegetal matrix with low fat content. Chemistry Central Journal 6: 8.

Juárez, M., Polvillo, O., Contò, M., Ficco, A., Ballico, S. \& Failla, S. 2008. Comparison of four extraction/methylation analytical methods to measure fatty acid composition by gas chromatography in meat. Journal of Chromatography A 1190(1): 327-332.

Jumat, S., Mamot, S., Suria, R.\& Mohamad, A.S.M.L. 2006. Oil and Fat Analysis. Bangi: Penerbit UKM.

Mossoba, M., Kramer, J.K.G., Milosevic, V., Milosevic, M. \& Azizian, H. 2007. Interference of saturated fats in the determination of low levels of trans fats (below $0.5 \%$ ) by infrared spectroscopy. Journal of the American Oil Chemists' Society 84(4): 339-342.

Mozaffarian, D., Katan, M.B., Ascherio, A., Stampfer, M.J. \& Willett, W.C. 2006. Trans fatty acids and cardiovascular disease. New England Journal of Medicine 354(15): 16011613.

Murrieta, C., Hess, B. \& Rule, D. 2003. Comparison of acidic and alkaline catalysts for preparation of fatty acid methyl esters from ovine muscle with emphasis on conjugated linoleic acid. Meat Science 65(1): 523-529.

Neo, Y.P., Tan, C.H. \& Ariffin, A. 2007. Fatty acid composition of five Malaysian biscuits (cream crackers) with special reference to trans-fatty acids. ASEAN Food Journal 14(3): 197-204.

Nimal Ratnayake, W. 2004. Overview of methods for the determination of trans fatty acids by gas chromatography, silver-ion thin-layer chromatography, silver-ion liquid chromatography, and gas chromatography/mass spectrometry. Journal of AOAC International 87(2): 523-539.

Phillips, K.M.,Ruggio,D.M. \& Amanna, K.R. 2010. Optimization of standard gas chromatographic methodology for the determination of trans fat in unlabeled bakery products. Food Analytical Methods 3(4): 277-294.

Pierluigi, D. \& Jeanne, I.R. 2007. Evaluation of gas chromatographic methods for the determination of trans fat. Anal. Bioanal. Chem. 389: 77-85.

Tang, T. 2002. Fatty acid composition of edible oils in the Malaysian market, with special reference to the trans-fatty acids. Journal of Oil Palm Research 14(1): 1-8.

Tarrago-Trani, M.T., Phillips, K.M., Lemar,L.E. \& Holden, J.M. 2006. New and existing oils and fats used in products with reduced trans-fatty acid content. J. Am. Diet Assoc. 106(6): 867-880. 
Taverniers, I., De Loose, M. \& Van Bockstaele, E. 2004. Trends in quality in the analytical laboratory. II. Analytical method validation and quality assurance. TrAC Trends in Analytical Chemistry 23(8): 535-552.

Wassell, P. \& Young, N.W.G. 2007. Food applications of trans fatty acid substitutes. International Journal of Food Science \& Technology 42(5): 503-517.

School of Chemical Sciences \& Food Technology

Faculty of Science and Technology

Universiti Kebangsaan Malaysia

43600 Bangi, Selangor

Malaysia
*Corresponding author; email: jumat@ukm.edu.my

Received: 11 January 2013

Accepted: 17 April 2014 